\title{
Tropical grey literature: no place to go?
}

\author{
C. J. STIGTER
}

Traditional Techniques of Microclimate Improvement (TTMI) Project, c/o Department of Meteorology, Wageningen Agricultural University, Duivendaal 2, NL 6701 AP Wageningen, Netherlands

Several years ago, Eugene Garfield, President of the Institute for Scientific Information, detailed in two of his Current Comments how badly the Third World scored in scientific publishing (Garfield, 1983). For instance, he showed that only $2 \%$ of all references belongs to authors based in the Third World. Recently his figure of a mere $5 \%$ contribution (over half from India) to world scientific output was still the same (Garfield 1988). When I drew attention to these quantitative results (Stigter, 1984), my main conclusions were that level and impact of Third World science are low but that any improvement should mainly come from research carried out by local scientists on locally relevant subjects, for example from agricultural and other environmental sciences, with support from scientifically more developed countries. I suggested that this would be in our own interest and Garfield (1988) agrees.

Nothing in the publishing world of agricultural research indicates much improvement or prospect, with the notable exceptions of international organizations such as those of the UN family, and international agricultural research institutes based in the Third World that have their own publishing units. In contrast, national research organizations, national universities and bilateral development projects there continue to face the same publishing problems. Except in India, the majority of local journals are either short-lived or have unacceptably long times between submission and issue. So they largely receive papers that have been refused by international journals elsewhere or are already known by their authors to be of low quality. With very few exceptions, which we all know from such journals as Current Contents, this perpetuates their low quality and lack of recognition.

It is our experience that besides a modest share in the pages of general journals, tropical researchers have access to only a few specialized international journals, where they may occasionally publish outstanding tropical research work (e.g. Gough et al., 1987; Coulson et al., 1988), or they may contribute to rather rare handbooks on tropical subjects (e.g. Stigter \& Darnhofer, 1989). Such channels appear not to cater for a large-scale exchange on approaches of and experience in tropical field work in what has been called 'grey literature'. However, we feel that this 'grey literature' is now likely to be the most needed exchange item in tropical agricultural research, because of the occurring differentiation of research with respect to target groups of farmers and their participation in the genesis, validation and use of advisories based on such 'grey results' (Stigter \& Rijks, 1988). So far, 


\section{J. STIGTER}

only some specialized international meetings in the Third World, for which the otherwise prohibitive funds are supplied by international bodies, or the forum sections of some new journals, provide us with limited opportunities for such an exchange (e.g. Coulson \& Stigter, 1988; 1989; Stigter et al., 1989).

I believe that a 'grey literature' synopsis system, among few, started six years ago in this journal would meet the need for communication of tropical 'grey results'. However, questions raised about counting such synposes as "real publications" apparently forced this journal to change its policy, so that now the only difference between a full paper and a synopsis is length. It looks as if the fear of having the 'value' of someone's publications measured quantitatively, instead of distinguishing different functions in the exchange of information, killed this 'grey literature' experiment.

The question remains. Where can we go for the easy world-wide exchange of field experience in tropical agriculture, especially that from national and bilaterally supported research? There appears to be no easy answer. Recent initiatives like the ILEIA (Information centre for Low External Input Agriculture) Newsletter deserve strong support, because they are at present the only alternatives (Stigter et al., 1987). But details of the struggles, the failures and the tentative solutions in tropical technical, scientific and extension/advisory research undertakings cannot all be channelled through such newsletters.

The international agricultural research institutes have failed to provide sufficient support for national tropical research systems in other matters than training. They are not taking sufficient initiative on matters of tropical information exchange other than for their own (certainly valuable) information. Which bilateral initiatives may be taken? For this purpose I would like to plead strongly for the cheap synopsis of the original 'grey literature' type tried earlier in this journal, to make results in internal reports more accessible. I am not asking for any compromise on quality of the reported results, but kind and quantity of results should be allowed to be different.Their main function should be to prevent us from having to invent the 'tropical wheel' time and again. If this function of such a synopsis is clearly defined, the 'counting' as a scientific publication becomes irrelevant, because it will be recognized that scientific publications of different catagories exist. If an appreciable number of scientific and technical journals in relevant fields would carry stch a clearly distinguishable synopsis section, devoted to what happens in the Third World, all scientists, technicians and other readers would stand to gain. Garfield (1988) recently postulated that many publishers are keen to help promote Third World science in any way they can. Here is a chance to prove it.

\section{References}

Coulson, C. L. \& C. J. Stigter, 1988. Appropriateness of instrumentation for agro-ecological research in low-income developing countries. Functional Ecology 2: 109-113.

Coulson, C. L. \& C. J. Stigter, 1989. Appropriateness of instrumentation in agroforestry/agricultural research in developing countries. In: W. E. Reifsnyder \& T. Darnhofer (Eds), Meteorology and Agroforestry. Proceedings of an ICRAF/WMO/UNEP Workshop on Application of Meteorology in Agroforestry Systems Planning and Management, Nairobi, Kenya. ICRAF, Nairobi, p. $305-314$. 
Coulson, C. L., C. J. Stigter, E. Akunda \& E. Floor-Drees, 1988. Instrument-based distortions of leaf/air temperature differences and interpretations of bean drought stress resistance. Tropical Agriculture 65: 352-354.

Garfield, E., 1983. Third World Research. Part 1. Where it is published and how often it is cited. Part 2. High impact journals, most-cited articles, and most-active areas of research. Current Comments in Current Contents 14 (33): 5-15 and 14 (34): 5-16.

Garfield, E., 1988. Supporting scientist-colleagues in the Third World is in our own best interest. Current Comments in Current Contents 19 (16): 3-7.

Gough, M. C., C. B. S. Uiso \& C. J. Stigter, 1987. Convection currents in bulk grain. Tropical Science 27: 29-37.

Stigter, C. J., 1983. Scientific Research in the Third World. Daily News (Tanzania), October 12th, p.4 (in an adapted Dutch translation published in Overzicht (NUFFIC) (1984) 13 (6): 7-8).

Stigter, C. J. \& the TTMI Teams in Kenya, Sudan \& Tanzania, 1987. Three papers in: Microclimate Management, ILEIA Newsletter 3 (3): 5-6, 7-8, 10-11.

Stigter, C. J. \& D. A. Rijks, 1988. Conclusions and Recommendations. In: D. A. Rijks \& C. J. Stigter (Eds), Agrometeorology of the Potato Crop, Proceedings of a WMO/KNMI/ICP/ISHS Symposium, Wageningen, Netherlands. Acta Horticulturae, Nr. 214 (special issue co-published by ISHS and WMO), p. 7-16.

Stigter, C. J., T. Darnhofer \& H. Herrera S., 1989. Crop protection from very strong winds: recommendations in a Costa Rican agroforestry case study. In: W. E. Reifsnyder \& T. Darnhofer (Eds), Meteorology and Agroforestry. Proceedings of an ICRAF/WMO/UNEP Workshop on Application of Meteorology in Agroforestry Systems Planning and Management, Nairobi, Kenya. ICRAF, Nairobi, p. 521-529.

Stigter, C. J. \& T. Darnhofer, 1989. Quantification of microclimate near the soil surface. Appendix F. In: J. M. Anderson \& J. S. I. Ingram (Eds), Tropical Soil Biology and Fertility: A Handbook of Methods, IUBS/UNESCO (MAB), CAB International, Wallingford (UK), p. 144-157. 